\title{
Immature Leukocyte Count
}

National Cancer Institute

\section{Source}

National Cancer Institute. Immature Leukocyte Count. NCI Thesaurus. Code C127625.

The determination of the number of immature leukocytes in a biological sample. 